\title{
12. The Labor Party Campaign and Aftermath
}

\author{
George Wright
}

\section{Disunity versus discipline}

Labor did not so much lose the election as lose government. In Australian football terms, we had put the Liberals 10 goals ahead when the year started. Labor's defeat in 2013 had been determined years earlier as we persisted with a jaw-dropping lack of unity and seemingly endless infighting. It is remarkable that, amid all of that, we advanced literally hundreds of legislative reforms. However, very few of those were noticed by the public as a result of the number of news stories on our disunity. Even though Kevin Rudd's opponents went silently after he resumed the leadership in June 2013, the years of infighting and undermining had left Labor in an unwinnable position.

The policy changes, the legislation passed, and the reforms delivered counted for very little against an overwhelming perception of disunity. All the Coalition had to do to win was hold their nerve when we inevitably made a comeback, as we did when Kevin Rudd resumed the Labor leadership. The crucial thing that the Coalition had in spades, and ruthlessly drove home their advantage with, was the biggest thing Labor's team lacked: discipline.

Any observer of politics would observe that really where the problems for the Labor Party started was when we removed a first-term prime minister [Kevin Rudd in 2010]. Whatever the details of our incapacity to get over that, the truth is that we never did.

Figure 1: Extract from George Wright's responses to questions following his address to the National Press Club, 29 October 2013

Source: Australianpolitics.com — <australianpolitics.com/2013/10/29/george-wright-alp-federal-electionanalysis.html>.

History will not remember the Coalition's campaign as brilliant, but it should be remembered as brilliantly disciplined. From their captain to their most junior backbencher they played like a team, and it worked. That meant the Liberals could align and manage their leader to the needs of their party's campaign 
strategy. They kept Opposition Leader Tony Abbott under tight control and resisted pressure to release detailed policies and costings until after the voters had already made up their minds.

The Coalition's research would have been telling them the same thing that ours was telling us: Mr Abbott was neither all that respected nor all that liked. The Liberal's determination to keep the focus off Tony Abbott and on Labor was executed with absolute precision. Yet despite all their campaign successes, and the ridiculously large target Labor presented, it should not be forgotten that the Coalition's primary vote at the 2013 election improved by only 1.8 per centthe lowest increase to the winning party on a change of government since the early 1940s.

Labor now stands to be a more competitive opposition than it was able to be in the first terms after the defeat of both the Whitlam (1975-77) and the Hawke/ Keating governments (1996-98). If the Liberals lose the number of seats at the next election that they lost to Kim Beazley in 1998 their majority will have been wiped out in one term. A one-term Abbott Government is possible with the unity and discipline Bill Shorten and the Labor team are showing. That would not be the case if our defeat had been more comprehensive.

Australians voted against the disunity and infighting of a Labor government which appeared more interested in itself than in the Australian people. Having changed leaders just weeks out from the likely election date, our campaign had to be the inverse of the one the Liberals undertook. It had to emphasise Kevin Rudd and his strengths and work the party's strategy into making the most of these, not the other way around. To do anything else would have been implausible.

\section{Pulling off a 'Dunkirk'}

For the party to install a new leader in such drawn out and dramatic circumstances meant our leader was always going to be in the spotlight. Prime Minister Kevin Rudd had earned the right - or perhaps accepted a duty - to campaign on his strategy.

Quite obviously, given the election outcome, we could not pull off the impossible victory. But by changing leaders back to Kevin Rudd, Labor did cauterise its potential losses. In the second quarter of 2013, our polling was telling us Labor was looking at being reduced to as few as 30 seats in the House of Representatives. Western Sydney looked like it would become a Liberal 
heartland. Queensland, Western Australia and South Australia all risked being reduced to a single Labor seat each, and we fully expected that Tasmania and the Northern Territory would return no Labor seats at all.

Eventually, we ended up holding 55 seats - six more than we held in 1996 and 19 more than we won in 1975. This was a solid loss and a bitter disappointment, but Labor did succeed in salvaging a team capable of being a strong opposition and a credible alternative government. As one commentator wrote, we pulled off a 'Dunkirk' evacuation - suffering a major defeat, but managing to escape with our army intact. We live to fight another day.

... I briefed the leader on the polling, and the leadership team. I didn't shop it round, I didn't leak it, I didn't do all of those things that have poisoned the Labor Party in the way that it deals with these things in recent years. I will not lead a national secretariat that indulges in that sort of stuff. I think that's the wrong thing for Labor, the wrong people, the wrong thing for the parliamentary party and I just won't have any truck with it. But of course I did brief the leadership on the state of the polling.

... I think there was a period when Kevin Rudd came back when there was a prospect of us achieving a highly unlikely victory at the election. He made a difference, he did make a difference. Yes he did. He campaigned extremely hard during the 2013 campaign. He threw everything that he had at it. He did make a difference and the change of leadership did make a difference. [In] the period immediately following him returning to the leadership, there was a very, very significant improvement in our numbers, and our numbers in the seats that we would need to be competitive in and win to win the election. We weren't able to sustain that to the line ...

\section{Figure 2: Extract from George Wright's responses to questions following his address to the National Press Club, 29 October 2013}

Source: Australianpolitics.com.

As Bill Shorten's new frontbench proves, Labor's Generation X MPs have saved their seats and that means Labor has good grounds for future optimism. Not only have we retained experienced parliamentarians like Jenny Macklin and Wayne Swan, we also gained a new generation of high calibre MPs like Claire O'Neill, Jim Chalmers, Pat Conroy and Tim Watts. 


\section{A new direction in campaigning}

So, why did we not suffer a greater loss? There is no doubt that the change to Labor's leadership was important, but there were other reasons beyond the leadership change which contributed to stemming our losses. At an organisational level we started work on strengthening our party's finances, reinvigorating our campaign capacity and working on the democracy deficit that has frustrated many of our members and put a strain on our grassroots connection with the community. On all of these objectives we still have much work to do, but we have made progress.

Over the past two years we have re-organised our finances and fundraising and eliminated a decade's worth of operating debt. That put us in a position to be able to invest earlier in our on-the-ground campaigning and in our relationship with the Labor community. Importantly, we have started to re-tool the way we engage with our members and supporters and how we campaign. Labor has started building a stronger, more inclusive and effective campaigning machine that will positively contribute to our competitiveness in future elections.

From here we intend to take Labor into a new third generation of large scale political campaigning. Unlike the two previous generations - which relied first almost exclusively on mass advertising, then second on demographic targeting - this third generation relies more heavily on direct and individual, one-on-one conversations and voter engagement, and the micro-targeting of information and messages to individuals. It requires better-trained, organised and resourced campaigners and supporters at every level of the party - and it will only work if we are truly willing to invite our supporters into our party and our campaigns. This type of campaigning requires widely accessible resources and many thousands of volunteers - but has a target audience of one.

A year out from the 2013 campaign we significantly increased the resources dedicated to digital and good old fashioned face-to-face campaigning. In the hands of good local members, trained local organisers and their campaign teams, this investment, I believe, made a material difference in a score of seats across the country.

Since 2011 we have increased by more than 10 times the size of our campaigning email list of potential volunteers and donors. Back then, our most popular online material was attracting around 50,000 views - in 2013 we were achieving as many as three million. We increased the amount of campaign funds raised from small donors by more than 13 times. Small online donors now contribute more than twice the campaign funds to federal Labor than any individual union or corporate contributor. This will have a significant and positive impact on our party into the future, and we will keep building on it. 
More than 12 months out from the 2013 election Labor also placed 40 full-time national organisers into the field across our most contested electorates. Their task was to build large volunteer networks which made more direct and faceto-face contact with voters than we ever have before. As just one example of this, the number of volunteer and candidate one-on-one phone calls to voters in our campaigns increased more than 12-fold between the 2010 and 2013 election campaigns.

In terms of who was running the campaign, I was campaign director and I take complete responsibility for it. It was a unique set of circumstances. So for example, in May we had a full trial of the campaign headquarters ... 150 people in the campaign headquarters in their roles, doing their jobs, set, ready to go. Two weeks out from the election we had to replace 110 of those people because of the change of leadership and the impact that had on people's interest and willingness to participate in the campaign. So there were massive logistical issues and strategy issues that we had to deal with in a very tight timeframe.

Was it a perfectly run, well-oiled machine campaign? No it wasn't. No it was not. Did we hold it together? I think we did. Did we fight to the line? I think we did. Did we leave Labor in a position from which it can rebuild and did Kevin leave Labor in a position from which it can rebuild? I think he did.

None of that is a criticism of Julia Gillard at all, for whom I have the greatest and deepest respect. I think history will be much, much kinder to Julia Gillard than contemporary politics has been. But politics is hard and it is unfair, and I think both Kevin and Julia would agree with that.

\section{Figure 3: Extract from George Wright's responses to questions following his address to the National Press Club, 29 October 2013}

Source: Australianpolitics.com.

None of this, of course, won us the election, but it did help Labor hold seats. In Parramatta, Julie Owens and her team knocked on more than 10,000 doors. In Greenway, Michelle Rowland's volunteers made phone contact with more than 50,000 households. In McEwen, Rob Mitchell's team of volunteer telecampaigners made thousands of calls right up until midday on 7 SeptemberRob won his seat by 380 votes. In the New South Wales seat of Kingsford Smith and Adelaide (SA) we held our ground against the tide. In Morton and Blair in Queensland, and in Fowler (New South Wales), we had swings to us. 
The leadership ballot which followed the election was a great success and a recent survey shows it was one supported by more than 90 per cent of our members and supporters. In the past two years as National Secretary I have overseen the conduct of three national ballots of all ALP members - for the party president, for membership of Labor's new National Policy Forum and most recently for the election of Labor's leader. The participation of Labor members in the direct election of our leader was an outrageous success. More than 4,500 new members joined the Labor Party since our 7 September election defeat.

This process delivered Bill Shorten the most solid platform that any Labor opposition leader anywhere in the country has had for a long, long time. It has been a shot in the arm for Labor and we must embrace it, build on it and drive it forward. These are the green shoots of a bigger, stronger and better Labor Party starting to come through. Labor lost the 2013 election, but we are in good shape to rebuild and wage an even stronger campaign next time. We continue to strengthen the party's financial resources, to improve the effectiveness of our local and national campaigning and to democratise the operation of our party. This is not an idealistic position or words we think we ought to say, it is a pragmatic reality - our supporters and members demand it of us and we cannot hope to win without them.

\section{The Rudd-Gillard legacy and Labor's vision for the future}

So what is the real significance of the 2013 election? The Rudd and Gillard governments kept Australia out of a world recession and struck out in new directions crucial to the future of our nation. Improving our schools, building a world class national broadband network (NBN), creating a modern early learning infrastructure, tackling climate change, extending the principles of Medicare to disability, greater equality for women, and many other things. The forward march of this Labor agenda may have been temporarily halted because the government failed to manage its time in office successfully, but that agenda has not yet fully played itself out.

There is an optimistic parallel here with the years 1975 to 1983 . When the Whitlam Government was defeated, it was not so much because of its program of reform but because of its management of reform. The things Whitlam introduced could not be consolidated without better political management, but they could not be stopped either. It was replaced by a government, led by Malcolm Fraser, which knew what it was against, but not what it was for. Labor 
under a new generation was able to get its act together sufficiently quickly to take advantage of the lack of purpose in Fraser's administration and the deterioration that inevitably resulted.

The circumstances of Labor's 2013 loss of government do not necessarily forebode a long time in opposition. If Labor can learn the necessary lessons, it can be back in government sooner than many think. The 2013 election may have been dominated by voters' distaste for Labor's instability - and the politics of the recent past. But it did not resolve the big questions voters really want answered about the future:

- Where is Australia headed?

- Where will our economy and community be in five, 10 and 20 years from now?

- Where will the jobs of the future come from beyond the China mining boom?

- Will I, or my kids, ever be able to afford to buy our own home?

- Will our education, health, broadband, roads and transport services help my family and my community get ahead - or will they leave me behind?

At the 2013 election, the Liberals won the past, but they did not win the future. This remains the greatest opportunity for Bill Shorten and Labor in opposition.

The progressive achievements, issues and programs on which Labor set its course during the Rudd and Gillard years won't be buried by the political rubble that era also created, or by the current Coalition Government. Tackling climate change, justice for people living with a disability, needs-based education funding, world-class broadband, equitable access to university, properly funded retirement incomes, fair workplace rights, balancing the demands of jobs and the environment; these issues will not be kicked off the national agenda. We must never walk away from them because they are our mandate. They speak to who we are and who we represent - and it is still only Labor that can truly progress them. 
For Labor to be successful, we must be a party that has broad appeal and a broad representation. We can't 'narrow-cast' in the way that the Greens do, or some of the other parties do. We are a party of government. And if you look at our history, I believe when we have been successful there has always been some coalition that we have been able to form between the more socially conservative working class and the more 'liberal' sort of better-heeled classes ... in any victory we've ever had, we've had to have both.

The Liberals have been expert at cleaving part of that more socially conservative, more traditional, Labor base away from us. I think it's what they built a lot of their success during the Howard era on and I think they're hoping that they will equally build their success in this era on that. But I don't believe that the issues that have caused that cleave for us over the past few years are as deep as the ones that caused that cleave during the Howard years. I don't think they are on as solid ground. I think they always do something about inner city 'trendies' - well, it used to be something different, it used to be 'elites' or something. They'd always have something about characterising us as alienated from our working class base.

But I think that is a challenge Labor always has to struggle with. It's a struggle the Liberals always have to struggle with, to some extent, between basically the party of big business interests - where they've said to big business, 'On this occasion, you will decide what the government spends money on and what it doesn't spend money on' - and having to get the support of more traditional working class voters. So both parties are in this field and competing, and you know, we win some, we lose some. But I don't think any of these things are permanent. I don't think there's any permanent drift in the Labor Party that means that we can't win those voters.

Figure 4: Extract from George Wright's responses to questions following his address to the National Press Club, 29 October 2013

Source: Australianpolitics.com. 
This text taken from Abbott's Gambit: The 2013 Australian Federal Election, edited by Carol Johnson and John Wanna, published 2015 by ANU Press, The Australian National University, Canberra, Australia. 